\title{
Effect of phosphorus with and without phosphate solubilizing bacteria on growth and yield of tomato
}

\author{
Saeed Ul Haq ${ }^{1 *}$, Gohar Ayub ${ }^{1}$, Sidra Saleem¹, Abid Khan ${ }^{2}$,
} Nadeem Khan ${ }^{1}$ and Seema Zubair ${ }^{3}$

1. Department of Horticulture, The University of Agriculture Peshawar-Pakistan

2. Department of Agronomy, The University of Agriculture Peshawar-Pakistan

3. Department of Maths State and Computer Science, The University of Agriculture Peshawar-Pakistan

*Corresponding author's email: saeedulhaq195@gmail.com

Citation

Saeed Ul Haq, Gohar Ayub, Sidra Saleem, Abid Khan, Nadeem Khan and Seema Zubair. Effect of phosphorus with and without phosphate solubilizing bacteria on growth and yield of tomato. Pure and Applied Biology. Vol. 9, Issue 3, pp2111-2121. http://dx.doi.org/10.19045/bspab.2020.90225

\begin{tabular}{llll}
\hline \hline Received: 11/03/2020 & Revised: 30/05/2020 & Accepted: 05/06/2020 & Online First: 18/06/2020 \\
\hline
\end{tabular}

\section{Abstract}

Tomato crop was evaluated for the effect of phosphorus and phosphate solubilizing bacteria, at Agricultural Research Station Buner, during March 2016. Randomized Complete Block Design was used, replicated three times. Different phosphorus levels $(0,50,75,100$ and $125 \mathrm{~kg}$ $\mathrm{ha}^{-1}$ ) with and without phosphate solubilizing bacteria (PSB) were used. The application of phosphorus (P) and phosphate solubilizing bacteria (PSB) significantly influenced all the studied parameters. Phosphorus @ $125 \mathrm{~kg} \mathrm{ha}^{-1}$ influenced early flowering (32days), maximum number of branches plant ${ }^{-1}(9.12)$, wider stem diameter $(1.26 \mathrm{~cm})$, maximum leaf area plant $^{-1}\left(2340.3 \mathrm{~cm}^{2}\right)$, increased plant height $(81.62 \mathrm{~cm})$, wider diameter of fruit $(17.21 \mathrm{~cm})$, maximum number of fruits plant ${ }^{-1}(64)$, higher yield (25.9 tons ha $\left.\mathrm{h}^{-1}\right)$, maximum root length $(14.62 \mathrm{~cm})$ and maximum fresh root weight $(89.92 \mathrm{gm})$. Application of phosphate solubilizing bacteria took minimum flowering days (31), maximum number of branches plant ${ }^{-1}(6.9)$, wider stem diameter $(1.2 \mathrm{~cm})$, increased plant height $(76.34$ $\mathrm{cm})$, wider fruit diameter $(13.62 \mathrm{~cm})$, maximum number of fruits plant ${ }^{-1}(63.56)$, higher fruit yield (24.6 tons $\left.\mathrm{ha}^{-1}\right)$, maximum root length $(14.27 \mathrm{~cm})$, and maximum fresh root weight $(87.94 \mathrm{gm})$, except leaf area plant ${ }^{-1}\left(1911 \mathrm{~cm}^{2}\right)$. Hence it is concluded that phosphorus @ $125 \mathrm{~kg} \mathrm{ha}^{-1}$, and seedlings inoculated with PSB resulted in maximum growth and yield in the study area.

Keywords: Bio fertilizer; Growth; Inorganic fertilizer; Solanum lycopersicum; Yield

\section{Introduction}

The tomato (Solanum lycopersicum) belongs to the family solanaceae, an important worldwide vegetable crop. The tomato crop was introduced from Europe to Indo-Pak sub-continent by the second half of the nineteenth century. In subcontinent tomato rapidly got flourished.
Annually tomato two crops are produced (summer and winter) in Pakistan. The winter crop is common to frost-free areas like Jaban Dargai [1]. In most of the tropical countries it is available throughout the year during the seasonal peaks June-October. Tomatoes are used in different forms, as a salad in raw 
form and also cooked in soups, sauces and stews etc. it is also used as a seasoning ingredient in various dishes in some regions. It is a source of a major antioxidant lycopene which has several health benefits such as reducing risk of heart diseases and cancer. They also have a good amount of vitamin $\mathrm{C}$, and $\mathrm{K}$, potassium and folate [2]. A number of factors determine the productivity of a crop, for tomatoes to produce best a warm weather for 3-4 month with a constant high temperature of $55^{\circ}-75^{\circ} \mathrm{F}$ is best. Tomatoes prefer deep, welldrained soil with a little sand and good amount of clay in subsoil. The $\mathrm{pH}$ of the soil should be around 6-6.8.In addition, soil nutrients also have great importance for plant's health and yield. The role of appropriate fertilizer to produce vigorous plants having more number of shoots, leaves, flowers and fruits cannot be denied. NPK are essential nutrients, for healthy growth and flowering. Fertilizer is also important for higher flower production and quality seed yield of crops [3]. Fertilizers are substances that contain most of the essential elements which have positive impact on plants growth. The application of fertilizer, boost up the tolerance of the plants to suppress diseases, insects, and weeds. These substances can also play a crucial role to prevail over the drought condition by raising the plant's ability to sustain more water and improve penetration of roots [4]. Phosphorus is very important to accelerate proper and vigorous growth of plants. The important functions that are related with $\mathrm{P}$ are: greater root growth, vigorous stalk and stem, qualitative formation of flower and seeds, crop earlier maturity and improved quality of crops [5]. Phosphorus is absorbed by the plants in the form of $\mathrm{H}_{2} \mathrm{PO}_{4}^{-1}$ - or $\mathrm{HPO}_{4}^{-2}$ ion. It quickly attaches with magnesium, iron and aluminum on soil particles, when applied under the low $\mathrm{pH}$ conditions [6]. $\mathrm{P}$ deficiency is very crucial chemical factor hindering growth of plant, therefore inorganic phosphate fertilizers are frequently used to get optimum yields. Soluble forms of $\mathrm{P}$ fertilizer are easily precipitated as insoluble forms leading to high and frequent applications of $\mathrm{P}$ fertilizers to the crop. The viable substitute of phosphorus supply through biological means, have been reported that phosphate solubilizing bacteria (PSB) and other $\mathrm{P}$ solubilizing agents help in exchange of insoluble phosphate to soluble primary and secondary orthophosphate ions [7]. PSB have great potential to make available the soil phosphates for plant growth. Phosphate bio fertilizer enhances the availability of complex $\mathrm{P}$ for growth of plant by solubilization [8]. Moreover, these microorganisms also play a vital role in the uptake of other essential elements and releasing of metabolites [9]. The ability of PSB to convert the insoluble phosphorus to the soluble form, allows a sustainable use of phosphate fertilizers [10]. Inorganic $P$ is mobilized and solubilized by organic and inorganic acids released by PSB in which $\mathrm{OH}^{-}$and $\mathrm{COH}^{-}$acids chelate cations "Al, $\mathrm{Fe}, \mathrm{Ca}$ " and also lowers the $\mathrm{pH}$ of alkaline soils, hence enhances the availability of certain other elements which likes low soil $\mathrm{pH}$ [11]. The purpose of the current study was to determine different levels of phosphorus, with and without bio fertilizer (PSB) and their interaction on growth and yield of tomato.

\section{Materials and methods}

The experiment was conducted at Agriculture Research Station Buner, Khyber Pakhtunkhwa during 2016. Randomized Complete Block Design (RCBD) was used with two factors and three replications. Tomato var. Roma was used as a study material. The nursery was raised during the month of February and transplantation of saplings were done in the month of March. Row to row distance was kept $75 \mathrm{~cm}$ and plant to plant distance $60 \mathrm{~cm}$. The size of the 
plot used was $1.5 \mathrm{~m} \times 2.4 \mathrm{~m}$ (Plot area $=3.6 \mathrm{~m}^{2}$ ). Bio fertilizer were used @2 $\mathrm{kg} \mathrm{ha} \mathrm{ha}^{-1}$.The PSB (Pseudomonas striata) contains $1 \times 10^{8}$ cells of bacteria per $\mathrm{kg}$. For inoculation of tomato seedlings slurry was prepared from $10 \%$ gur solution, PSB and media (vegetable oil, saw dust, sucrose) and seedlings were kept in it for 10-15 mints under shed before transplanting. A uniform fertilizer dose of $150 \mathrm{~kg}$ Nitrogen and $75 \mathrm{~kg} \mathrm{~K}_{2} \mathrm{O}$ per hectare was applied in the form of urea and sulphate of potash (SOP). The nitrogen dose was split into two equal applications. The soil of experimental site was analyzed for its physiochemical properties before and after the experiment, the findings of which are given in (Table 1).

Table 1. The Physio-Chemical properties of the experimental site

\begin{tabular}{|c|c|c|}
\hline Soil Characteristics & Sample (Before experiment) & Sample (After experiment) \\
\hline Ec $(1: 5) \mathrm{dsm}^{-1}$ & 0.45 & 0.55 \\
\hline $\mathrm{pH}$ & 8 & 7.5 \\
\hline Organic matter & 1 & 1.2 \\
\hline Total Nitrogen \% & 0.05 & 0.07 \\
\hline Available P $\left(\mu \mathrm{g} \mathrm{g}^{-1}\right)$ & 11.25 & 14.56 \\
\hline Exchangeable K $\left(\mu \mathrm{g} \mathrm{g}^{-1}\right)$ & 120.54 & 124.24 \\
\hline
\end{tabular}

\section{Studied parameters}

Data were recorded on the following parameters

\section{Days to flowering}

Days to flowering were counted from date of sowing to $50 \%$ flowering in each plot.

\section{Number of branches plant ${ }^{-1}$}

In each plot five plants were selected randomly, the branches of each plant were counted and their average was taken.

\section{Stem diameter $(\mathrm{cm})$}

Five plants were randomly selected, and beneath first branch raised, diameters were measure with the help of Vernier caliper.

\section{Leaf area $\left(\mathrm{cm}^{2}\right)$ plant ${ }^{-1}$}

The leaf area of selected plants in each plot was calculated by leaf area machine., first at blooming stage, second after first picking and third prior last picking.

\section{Plant height $(\mathbf{c m})$}

Height of selected plants was measured with the help of measuring tape and their average was taken.

\section{Fruit diameter (cm)}

From each plot of all treatments five fruits were selected, and their diameters were calculated with the help of Vernier caliper.

\section{Number of fruits plant ${ }^{-1}$}

Number of the fruits was counted by the number of fruits picked from each selected plant.

Yield (tons ha $^{-1}$ )

Yield tons $\mathrm{ha}^{-1}$ of tomato fruits was calculated by the following formula.

Yield (tons ha' $\left.\mathbf{h a}^{-1}\right)=\left(\frac{\text { Yield per plot }(\mathrm{kg})}{\text { Area per plot }} \times\right.$ 10000)/1000

\section{Root length (cm)}

The root length was taken after the picking of fruits, selected plants were dugged out, and their roots were rinsed with water and with the help of measuring tape root length were measured.

\section{Root weight (g)}

The selected plants from each treatment were uprooted and rinsed with water to remove the adhering soil and weighed by digital balance and average was calculated.

\section{Statistical analysis}

The collected data was analyzed statistically by Statistix 8.1 while for means comparison LSD-test with 5\% probability level was used, and for graphical presentation SigmaPlot 10.0 was used.

\section{Results and discussion}


Days to flowering, number of branches plant $^{-1}$, stem diameter, leaf area plant ${ }^{-}$ 1, plant height

The analysis of the data showed highly significant effects of various phosphorus levels, PSB and their interaction on the studied attributes except leaf area. The mean values are presented in (Table 2, Fig.1). Among the phosphorus levels, the minimum days to flowering (32days), maximum number of branches plant ${ }^{-1}$ (9.12), wider stem diameter $(1.26 \mathrm{~cm})$, wider leaf area plant ${ }^{-1}\left(2340.3 \mathrm{~cm}^{2}\right)$, and maximum plant height $(81.62 \mathrm{~cm})$ was recorded in plants supplied with phosphorus @ $125 \mathrm{~kg} \mathrm{ha}{ }^{-1}$, while maximum days to flowering (42days), less number of branches plant $^{-1}(3.32)$, thin stem diameter $\left(0.65 \mathrm{~cm}^{2}\right)$, smaller leaf area plant ${ }^{-1}\left(1544.6 \mathrm{~cm}^{2}\right)$, and minimum plant height $(60.01 \mathrm{~cm})$ was noted in control plots. Concerning PSB data less number of days to flowering (31days), maximum number of branches plant $^{-1}$ (6.74), wider stem diameter (1.24 $\mathrm{cm})$, wider leaf area plant ${ }^{-1}\left(1911.9 \mathrm{~cm}^{2}\right)$, and maximum plant height $(76.33 \mathrm{~cm})$ was observed with PSB, while maximum days to flowering (43days), less number of branches $\operatorname{plant}^{-1}(5.86)$, thin stem diameter $\left(0.85 \mathrm{~cm}^{2}\right)$, smaller leaf area plant $^{-1}\left(1904.8 \mathrm{~cm}^{2}\right)$, and minimum plant height $(66.7 \mathrm{~cm})$ was noted in without PSB plots. Regarding the interaction of phosphorus levels and PSB, minimum days to flowering (26days), maximum branches plant ${ }^{-1}$ (12.17), and maximum plant height $(93.76 \mathrm{~cm})$ was recorded in plots supplied with phosphorus @ $125 \mathrm{~kg}$ $\mathrm{ha}^{-1}$ along with PSB treatment. However, wide stem diameter $(1.55 \mathrm{~cm})$ was observed with phosphorus@100kg ha ${ }^{-1}$ with PSB, while maximum days to flowering (48days), less number of branches plant $^{-1}(2.62)$, thin stem diameter $\left(0.62 \mathrm{~cm}^{2}\right)$, and minimum plant height $(58.95 \mathrm{~cm})$ was recorded for control without PSB plots (Fig. 2).

Table 2. The influence of Phosphate solubilizing bacteria and Phosphorus levels on different growth characteristics of Tomato

\begin{tabular}{|l|c|c|c|c|c|}
\hline PSB & $\begin{array}{c}\text { Days to } \\
\text { flowering }\end{array}$ & $\begin{array}{c}\text { No. branches } \\
\text { plant }^{-1}\end{array}$ & $\begin{array}{c}\text { Stem diameter } \\
(\mathbf{c m})\end{array}$ & $\begin{array}{c}\text { Leaf area } \\
\text { plant }^{-1}\end{array}$ & $\begin{array}{c}\text { Plant height } \\
(\mathbf{c m})\end{array}$ \\
\hline without & $43 \mathrm{a}$ & $5.86 \mathrm{~b}$ & $0.85 \mathrm{~b}$ & 1904.8 & $66.66 \mathrm{~b}$ \\
\hline with & $31 \mathrm{~b}$ & $6.74 \mathrm{a}$ & $1.24 \mathrm{a}$ & 1911.9 & $76.33 \mathrm{a}$ \\
\hline \multicolumn{6}{|c|}{ Phosphorus } \\
\hline cong ha $\left.\mathbf{~ h}^{-\mathbf{1}}\right)$ \\
\hline $\mathbf{5 0}$ & $42 \mathrm{a}$ & $3.32 \mathrm{~d}$ & $0.65 \mathrm{~d}$ & $1544 \mathrm{e}$ & $60.01 \mathrm{~d}$ \\
\hline $\mathbf{7 5}$ & $40 \mathrm{~b}$ & $5.56 \mathrm{c}$ & $1.00 \mathrm{c}$ & $1694 \mathrm{c}$ & $64.75 \mathrm{c}$ \\
\hline $\mathbf{1 0 0}$ & $37 \mathrm{c}$ & $7.32 \mathrm{c}$ & $1.09 \mathrm{~b}$ & $1876 \mathrm{~b}$ & $74.83 \mathrm{~b}$ \\
\hline $\mathbf{1 2 5}$ & $34 \mathrm{~d}$ & $6.19 \mathrm{~b}$ & $1.24 \mathrm{a}$ & $2085 \mathrm{~b}$ & $76.28 \mathrm{~b}$ \\
\hline Interaction & $32 \mathrm{e}$ & $9.12 \mathrm{a}$ & $1.26 \mathrm{a}$ & $2340 \mathrm{a}$ & $81.62 \mathrm{a}$ \\
\hline
\end{tabular}

PSB: phosphate solubilizing bacteria, NS: non-significant 


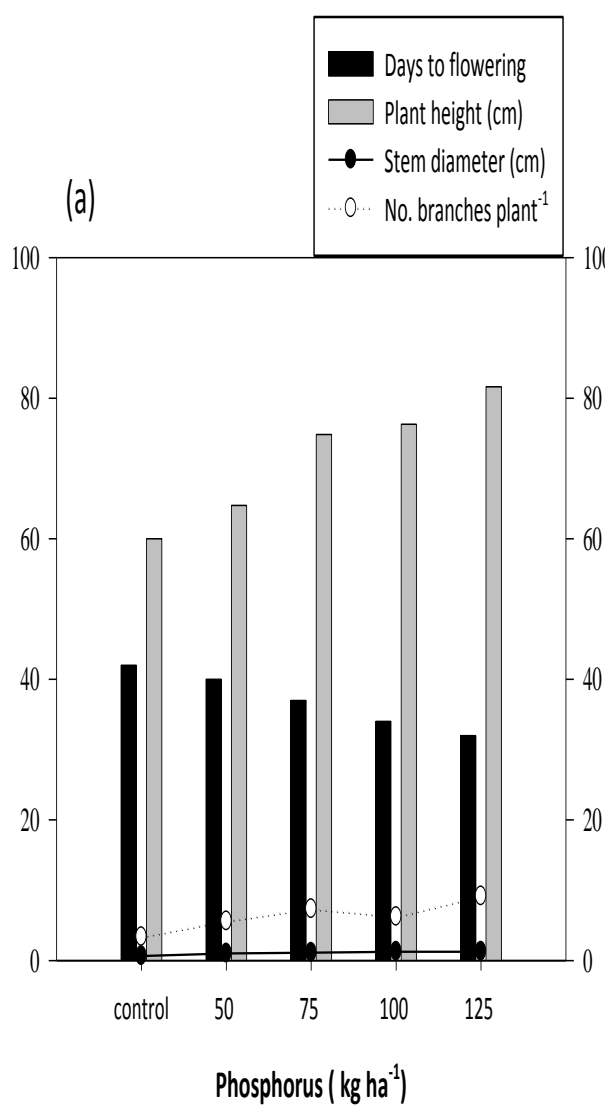

(b)
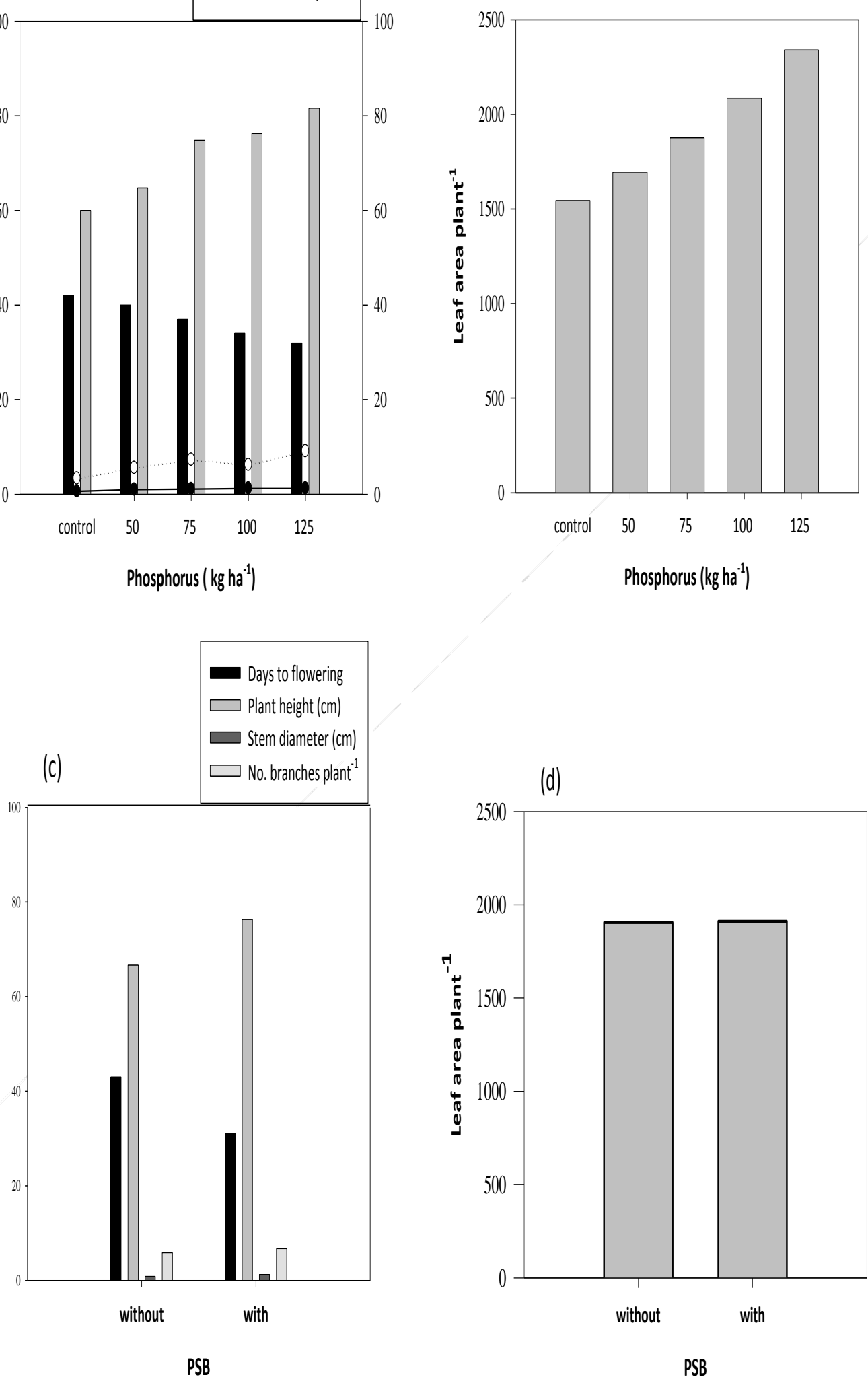

Figure 1. The effect of Phosphorus levels and Phosphate solubilizing bacteria on growth and yield characteristics of Tomato 
Haq et al.
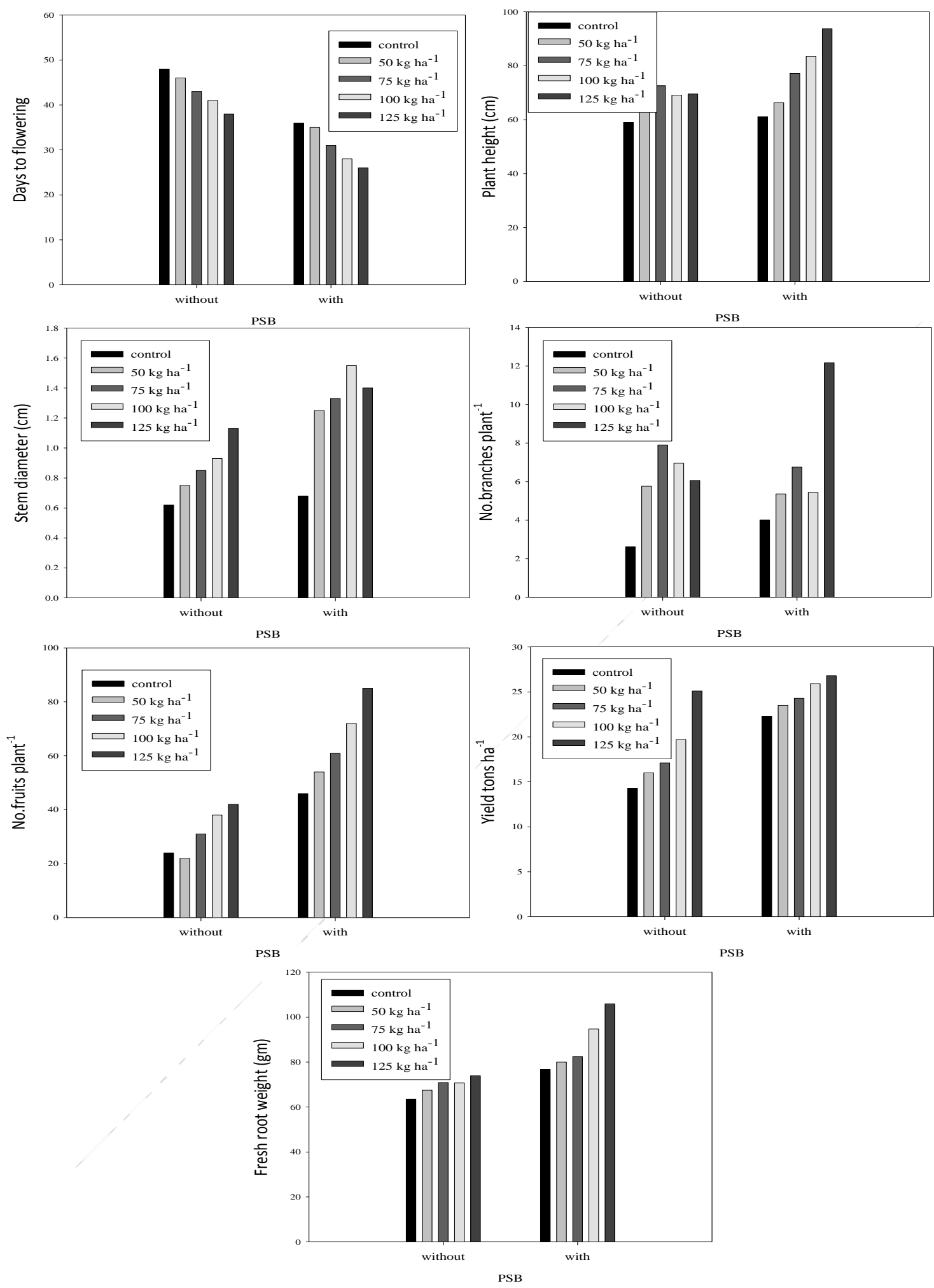

Figure 2. The interactive effect of Phosphate solubilizing bacteria and Phosphorus levels on growth and yield characteristics of Tomato 
Phosphorus being an essential component of ATP plays a vital role in plant biochemical reactions such as photosynthesis, respiration, cell division and enlargement and various other important processes in plants. [12] found that phosphorus enhanced the vegetative growth, and yield contributing characteristics, such as plant height, number of branches, leaf area, number of fruits plant ${ }^{-1}$,fruit yield with phosphorus @80 kg ha ${ }^{-1}$. [13] found that in protoplasm and chlorophyll phosphorus is the basic component which helps to convert photosynthates into phospholipids, ensuring proper vegetative growth and flowering. The maximum dose of phosphorus (200 kg ha-1) cause adverse effects on time of flowering, flower number and size of flower. Phosphorus is necessary for the general health and vigor of all plants. Out of $100 \%$ only $10-20 \%$ of the applied phosphorus fertilizer is available for the plants, while the remaining amount converts to insoluble phosphate by making a complex with calcium and magnesium. Similar results were also found by $[14]$. $[15,16]$ found that the application of bio fertilizer increase total tomato yield, brings early maturity and improves quality of crop. Insoluble inorganic phosphates become available to the plants by the help of PSB. PSB helps in $\mathrm{P}$ uptake, solubilization and mobilization. The capability of these microorganisms is mentioned to have one of the vital roles in relation to plant phosphorus availability. The biological supply of $\mathrm{P}$ is a viable substitute through phosphate solubilizing bacteria [7] In line with these findings [17] also observed that application of bio fertilizers had significant effect on plant height and number of branches plant ${ }^{-1}$. [18] Reported that various fertilizer (NPK) along PSB treatments significantly increased plant height $(164.24 \mathrm{~cm})$ and number of branches plant ${ }^{-1}(7.85)$. They attributed these increases in growth characteristics to the increased availability of phosphorus and auxin production under the influence of PSB. These reports are also in line with the findings of [19]. [20] Observed that leaf area and stem diameter was significantly enhanced by the application of PSB along the recommended dose of fertilizer (NPK; 250:250:250 kg). The application of PSB and inorganic fertilizer at proper stage and levels enhances fertilizer use efficiency of plants, leading to higher vegetative growth through the production of metabolites and its translocation particularly auxin, which promotes growth by increase cell division and cell enlargement.

Number of fruits plant $^{-1}$, fruit diameter, yield (tons ha-1), root length, fresh root weight

Highly significant differences were found among various treatments and their interaction; their mean values are presented in (Table 3, Fig. 3). Concerning phosphorus levels maximum number of fruits plant $^{-1}(63)$, maximum fruit diameter $(17.21 \mathrm{~cm})$, maximum yield (25.9 tons $\mathrm{ha}^{-1}$ ), maximum root length $(14.4 \mathrm{~cm})$, and maximum fresh root weight $(89.9 \mathrm{gm})$ was recorded in plants fertilized with phosphorus @125 kg ha ${ }^{1}$, while minimum number of fruits plant $^{-}$ ${ }^{1}(35)$, minimum fruit diameter $(7.22 \mathrm{~cm})$, minimum yield (18.3 tons $\left.\mathrm{ha}^{-1}\right)$, minimum root length $(10.5 \mathrm{~cm})$, and minimum fresh root weight $(70.1 \mathrm{gm})$ was observed in control plots. Regarding PSB treatment, maximum number of fruits plant $^{-1}(64)$, maximum fruit diameter $(13.62 \mathrm{~cm})$, maximum yield (24.6 tons $\mathrm{ha}^{-1}$ ), maximum root length $(14.3 \mathrm{~cm})$, and maximum fresh root weight $(87.9 \mathrm{gm})$ was noticed with PSB application, whereas minimum number of fruits plant $^{-1}(31)$, minimum fruit diameter $(12.71 \mathrm{~cm})$, minimum yield $\left(18.4\right.$ tons ha ${ }^{-}$ $\left.{ }^{1}\right)$, minimum root length $(10.6 \mathrm{~cm})$, and minimum fresh root weight $(69.3 \mathrm{gm})$ was noted in without PSB plots. The interaction of phosphorus and PSB was 
also found significant for the stated attributes except fruit diameter and root length. In this case the maximum number of fruits plant $^{-1}(85)$, maximum yield (26.8 tons $\left.\mathrm{ha}^{-1}\right)$, and maximum fresh root weight (105.9 gm) was recorded at $125 \mathrm{~kg} \mathrm{ha}^{-1}$ phosphorus along with PSB treatment, while least number of fruits plant $^{-1}(22)$, minimum yield (14.3 tons $\left.\mathrm{ha}^{-1}\right)$, and minimum fresh root weight $(63.5 \mathrm{gm})$ was recorded at $50 \mathrm{~kg}$ $\mathrm{ha}^{-1}$ phosphorus and at control respectively in without PSB plots (Fig. 2).

[21] stated that the yield contributing factors such as number of fruits plant ${ }^{-1}$, fruit weight, length, fruit diameter and total yield were significantly affected by organic and inorganic sources of nutrients along phosphate solubilizing bacteria. Among different treatment of nutrients along PSB the maximum number of fruits plant $^{-1}$, fruit diameter, and total yield was recorded with the integrated application of recommended dose of fertilizer and PSB. They stated that the increase in the yield contributing factors might be due the overall action of phosphorus and other nutrients which help in auxin synthesis. Auxin a growth promoting hormone, leads to increased cell division and elongation by increasing cell's water and osmotic solutes permeability. It also plays a great part in the synthesis of specific enzymatic proteins and m-RNA, which increases cell elasticity and extension, ultimately results in cell enlargement [22]. Besides, the higher yield could also be due to more uptake of nutrients by the plants under the influence of PSB, $[21,23]$ also found similar results. [18] reported a positive effect of the combined application of PSB and inorganic fertilizer on fruit yield of tomato. They attributed the enhancement of fruit yield to an improve shoot and root growth which results in higher yield characteristics. The organic acids released by PSB helps in solubilization of insoluble phosphates to soluble form and in mineralization of organic $\mathrm{P}$. These microorganisms consequently serve as a source of $\mathrm{P}$ in soils for plants. These results are also in line with the findings of [24] in tomato. [25] Stated that a significant difference of phosphate solubilizing bacterial isolates and control strain was found on shoot and root length, and fresh and dry weight of roots in tomato. A mean root length of $(28.9 \mathrm{~cm})$ and fresh root weight $(11.65 \mathrm{gm})$ was recorded in PSB treated plants as compared to control. The improved root characteristics can be attributed to higher levels of soluble phosphate and their availability to the plants in soil..

Table 3. The influence of Phosphate solubilizing bacteria and Phosphorus levels on different yield and root characteristics of Tomato

\begin{tabular}{|l|c|c|c|c|c|}
\hline PSB & $\begin{array}{c}\text { Fruit diameter } \\
(\mathbf{c m})\end{array}$ & $\begin{array}{c}\text { No. of fruits } \\
\text { plant }^{-1}\end{array}$ & $\begin{array}{c}\text { Yield } \\
\text { tons ha }^{-1}\end{array}$ & $\begin{array}{c}\text { Root length } \\
(\mathbf{c m})\end{array}$ & $\begin{array}{c}\text { Fresh root weight } \\
(\mathbf{g})\end{array}$ \\
\hline without & $12.71 \mathrm{~b}$ & $31 \mathrm{~b}$ & $18.4 \mathrm{~b}$ & $10.3 \mathrm{~b}$ & $69.3 \mathrm{~b}$ \\
\hline with & $13.62 \mathrm{a}$ & $64 \mathrm{a}$ & $24.6 \mathrm{a}$ & $14.3 \mathrm{a}$ & $87.9 \mathrm{a}$ \\
\hline \multicolumn{7}{|c|}{${\text { Phosphorus }\left(\mathbf{k g ~ h a}^{-\mathbf{1}}\right)}$} \\
\hline control & $7.22 \mathrm{e}$ & $35 \mathrm{e}$ & $18.3 \mathrm{~d}$ & $10.5 \mathrm{~d}$ & $70.1 \mathrm{~d}$ \\
\hline $\mathbf{5 0}$ & $11.54 \mathrm{~d}$ & $38 \mathrm{~d}$ & $19.8 \mathrm{c}$ & $10.6 \mathrm{~d}$ & $73.8 \mathrm{c}$ \\
\hline $\mathbf{7 5}$ & $14.04 \mathrm{c}$ & $46 \mathrm{c}$ & $20.7 \mathrm{c}$ & $12.2 \mathrm{c}$ & $76.7 \mathrm{c}$ \\
\hline $\mathbf{1 0 0}$ & $15.82 \mathrm{~b}$ & $55 \mathrm{~b}$ & $22.8 \mathrm{~b}$ & $13.6 \mathrm{~b}$ & $82.7 \mathrm{~b}$ \\
\hline $\mathbf{1 2 5}$ & $17.21 \mathrm{a}$ & $63 \mathrm{a}$ & $25.9 \mathrm{a}$ & $14.4 \mathrm{a}$ & $89.9 \mathrm{a}$ \\
\hline Interaction & $\mathrm{NS}$ & 3.21 & 1.77 & $\mathrm{NS}$ & 4.11 \\
\hline
\end{tabular}



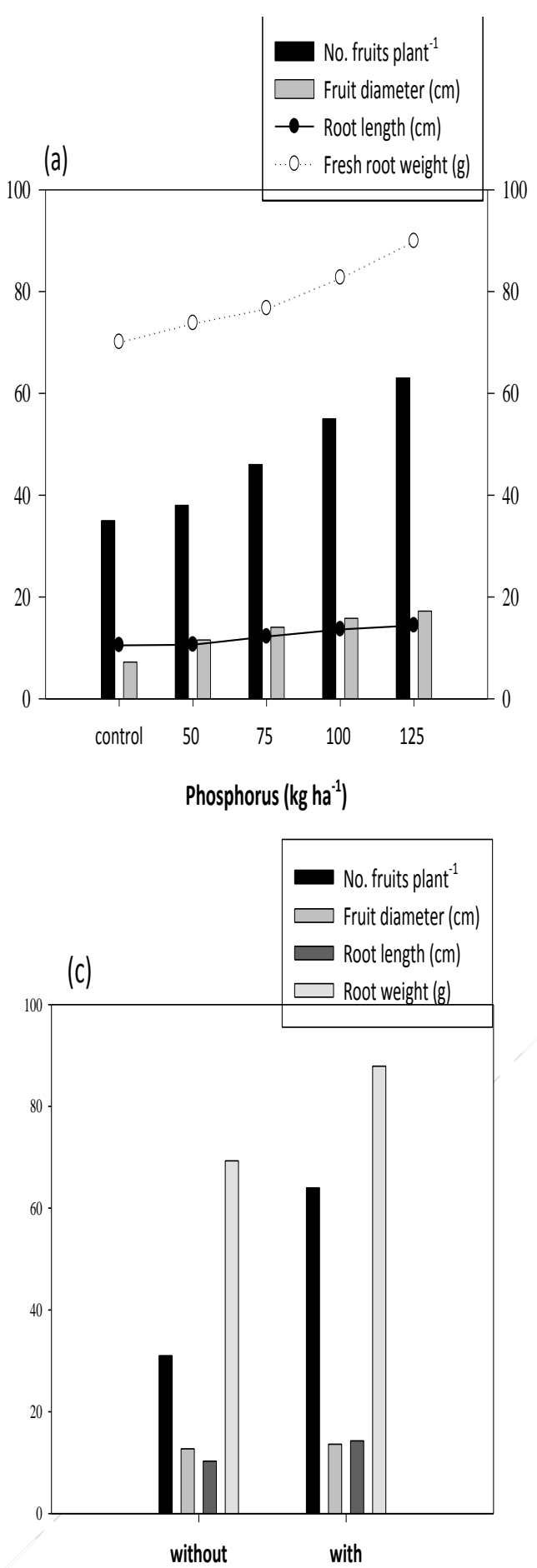

PSB (b)
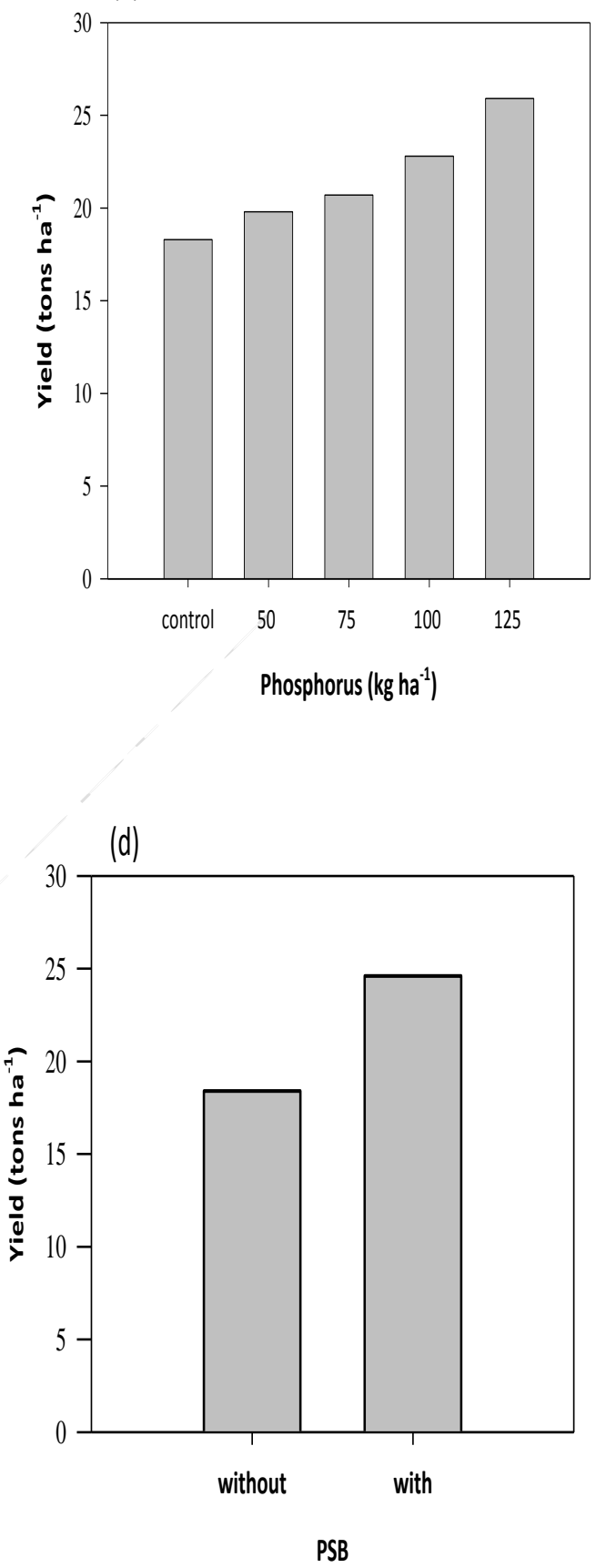

PSB: phosphate solubilizing bacteria

Figure 3. The effect of Phosphorus levels and Phosphate solubilizing bacteria on growth and yield characteristics of Tomato

\section{Conclusion}

In current study, five levels of phosphorus with and without phosphate solubilizing bacteria were used for growth and yield enhancement in tomato, which revealed significant effects on studied parameters. Among different phosphorus levels, phosphorus @ $125 \mathrm{~kg}$ ha $^{-1}$ along with PSB treatment proved to be most effective, hence it is recommended for better growth and yield of tomato. 
Authors' contributions

Conceived and designed the experiments: $\mathrm{G}$ Ayub, Performed the experiments: S Ul Haq, Analysed the data: S Ul Haq, Contributed materials/ analysis/ tools: S U1 Haq, Wrote the paper: S Saleem.

\section{References}

1. Shahid R (1999). The effect of calcium in prolonging the shelf life of tomato. Thesis submitted to the Dept of Hort KPK Agric Univ Peshawar pp 36.

2. Bjarnadottir A MS \& RDN (Ice) (2019). Tomatoes 101: Nutrition Facts and Health Benefits. https://www.healthline.com/nutrition/f oods/tomatoes

3. Kashif N (2001). Effect of NPK on growth and chemical effect on vaselife of Zinnia. MSc Thesis. PMAS Arid Agri. Univ Rawalpindi Pakistan pp 23.

4. Alam SM \& Khan MA (1999). Importance of Fertilizers. www.pakistaneconomist.com

5. Taiz L \& Zeiger E (2003). Plant physiology. (3rd Ed) Sinauer associates pp 623.

6. Mohanty BK (2002). Studies on variability, heritability inter relationship and path analysis in tomato. Ann Agric Res 2(1): 65-69.

7. Chabot R, Antoun H \& Cescas MP (1993). Stimulation of growth of maize and lettuce by inorganic phosphorus solubilizing microorganisms. Canadian $J$ Microbiol 39: 941-47.

8. Goldstein AH (1986). Bacterial phosphate solubilization. Historical perspective and future prospects. Am $J$ Alt Agric 57-65.

9. Gyaneshwar P, Kumar GN \& Parekh LJ (2002). Effect of buffering on the phosphate solubilizing ability of microorganisms. World J Microbiol Biotech 14: 669-673.

10. Gyaneshwar P, Naresh KG \& Parekh LJ (1998). Cloning of mineral phosphate solubilizing genes from
Synechocystis. PCC 6803 P Curr Sci 74: 1097-1099.

11. Stevenson FJ (2005). Cycles of Soil: Carbon Nitrogen Phosphorus Sulfur Micronutrients. John Wiley and Sons New York.

12. Rahman MA, Kawochar MA, Rahman MM, Pramanik MHR, Hossain ASMA. (2001). Growth and yield performance of tomato genotypes as influenced by phosphorus. $J$ Expt Biol Sci 2(1): 79-84.

13. Monish CR, NK \& Painaik P (2008). Effect of phosphorus on earliness flowering in pepper. $J$ Veg Hort 5(1): 67-68.

14. Sajid M \& Amin N (2014). Effect of various combinations of nitrogen, phosphorus and potash on enhancing the flowering time in Chrysanthemum (Chrysanthemum morifolium). Inter J Bio Sci 4(10): 99-108.

15. Tringovska I (2004). Influence of bacterial fertilizers on biological manifestations of tomatoes. Int Proceeding of Ecology and Health Conference Plovdiv-Bulgaria 20 May, Agricultural University pp 233238.

16. Tringovska I \& Kanazirska V (2008). Influence of bioproducts and the method of their application on greenhouse tomato productivity. Plant Sci 45(2):7-13.

17. Premsekhar M \& Rajashree V (2009). Influence of bio-fertilizers on the growth characters, yield attributes, yield and quality of tomato. American Eur J Sust Agric 3(1): 68-70.

18. Ahmad ZB, Tahir S, Fozia WS, \& Basharat H (2017). Impact of Phosphate Solubilizing Bacteria and Inorganic Fertilizers on Yield Attributes of Tomato. Inter J Curr Microbiol Appl Sci 6(6): 3233-3239.

19. Poonia MK \& Dhaka BL (2012). Effect of phosphorus solubilizing bacteria (PSB) on growth and yield in tomato. J Hort Sci 1: 104-107. 
20. Mudasir MM, Chattoo S, Faheema AP \& Parry FA (2012). Influence of organic and inorganic nutrients on growth and yield attributes of tomato. The Asian J Hort 7:337-339.

21. Siddaling N, Kempegowda K \& Raghavendra H (2017). Effect of Integrated Nutrient Management on Growth and Yield of Tomato (Solanum lycopersicum L.) var. Arka Rakshak. Inter J Plant \& Soil Sci 16(2): 1-7.

22. Gosavi PU, Kambale PAB (2010). Effect of organic and bio fertilizer on quality of tomato fruits. The Asian $\mathrm{J}$ Hort 5: 376-378.

23. Ranjit C \& Bandopadhya YS (2014). Studies on effect of organic inorganic and bio fertilizers on plant nutrient status and availability of major nutrients in tomato. Inter $J$ Bio-Resources and Stress Mgt 5: 9397.

24. El-Tantawy ME \& Mohamed MA (2009). Effect of Inoculation with Phosphate Solubilizing Bacteria on the Tomato Rhizosphere Colonization Process, Plant Growth and Yield under Organic and Inorganic Fertilization. J Appl Sci Res 5: 1117-1131.

25. Pathak R, Paudel V, Shreshta A, Lamichhane J \& Gauchan DP (2017). Isolation of phosphate solubilizing bacteria and their use for plant growth promotion in tomato seedling and plant. Kathmandu Univ J Sci Eng And Tech 13(2): 61-70. 